\title{
Riyadhah Puasa Sebagai Model Pendidikan Pengendalian Diri untuk Pemenuhan Kebutuhan Fisiologis
}

Husnul Hidayati

Kantor Kementrian Agama Kabupaten Bantul, Yogyakarta, Indonesia

Email: hidayatih71@gmail.com

\begin{abstract}
Abstrak
Untuk mencapai kepuasan, manusia dituntut untuk memenuhi kebutuhan dasarnya, salah satu kebutuhan yang paling dasar bagi manusia adalah kebutuhan fisiologis (physiological needs). Namun, untuk mencapai kepuasan tersebut, manusia harus mampu mengendalikan nafsunya sehingga mereka tidak lantas hanyut menuruti nafsu yang meluap-luap. Penelititan ini bertujuan menemukan peran riyadhah puasa sebagai bentuk pendidikan pengendalian diri dalam memenuhi kebutuhan fisiologis manusia. Temuan penelitian menunjukkan bahwa riyadhah puasa yang dijalani oleh santri Pondok Pesantren Al-Munawwir selama tiga tahun tanpa henti membantu mereka dalam menentukan batas kebutuhan yang sebenarnya mereka butuhkan. Selain itu, mereka juga lebih mengenali diri mereka sendiri, dan lebih tenang dalam menjalani hidup.
\end{abstract}

Kata kunci: riyadhah puasa, kebutuhan dasar manusia, kebutuhan fisiologis 


\title{
Riyadhah of Fasting as Self-Control Educational Model for Achieving Physiological Needs \\ Husnul Hidayati \\ Kantor Kementrian Agama Kabupaten Bantul, Yogyakarta, Indonesia \\ Email: hidayatih71@gmail.com
}

\begin{abstract}
To achieve satisfaction, humans are required to fulfill their basic needs. One of the most basic needs for humans is physiological needs. However, to achieve this satisfaction, humans must be able to control their lusts so that they do not necessarily drift into obedience. This research aims to find the role of fasting riyadhah as a form of self-control education in meeting human physiological needs. The research findings show that the fasting riyadhah lived by Al-Munawwir Islamic Boarding School students for three years endlessly helped them in determining the limits of the actual needs they needed. In addition, they also recognize themselves better, and are more calm in life.
\end{abstract}

Keywords: fasting riyadhah, basic human needs, physiological needs

\section{PENDAHULUAN}

Manusia sering kali dihadapkan pada pertanyaan mengapa ia hidup dan apa tujuan hidupnya. Hal yang mendasari munculnya pertanyaan ini adalah kebutuhan untuk mengidentifikasi apa yang akan membuat seseorang benar-benar puas (satisfied), dan pertanyaan tentang bagaimana menemukannya. Dalam disiplin keilmuan psikologi, metode psikoanalis mengklaim bahwa pemenuhan terhadap dorongan biologis bawaan (basic biological needs) akan membawa manusia kepada kepuasan. Sedangkan perspektif behavioris (behaviorism) menggambarkan pentingnya memenuhi 
kebutuhan fisiologis (pshysiological needs) seperti makanan, tidur, dan kebutuhan seks, sebagai hal yang akan membawa kepuasan. ${ }^{1}$

Dalam upaya memenuhi kebutuhan fisiologis tersebut, manusia sering kali tidak mampu menemukan batas dari kebutuhan yang harus dipenuhi. Konsekuensinya, manusia lalu secara "kalap" , dengan berbagai cara terus menerus menuruti keinginan pemenuhan kebutuhan fisiologis itu tanpa batas. Sehingga, manusia mengabaikan dampak negatif dari konsumsi berlebihan tersebut yang sering diartikan sebagai perilaku impulsif (impulsive behavior). Perilaku tanpa memikirkan dampak jangka panjangnya itu lalu menimbulakn masalah-masalah barui pada kondisi kejiwaan seseorang. Sehingga mereka mencari "sesuatu yang lain" yang mampu membawa mereka kepada kebahagiaan.

Merespon kecenderungan tersebut, gelombang baru pemikiran psikoterapi (psychotheraphy) pada awal hingga pertengahan abad ke20 percaya bahwa jalan menuju pemenuhan kebutuhan batin jauh lebih penting dan lebih kompleks. ${ }^{2}$ Salah satu aspek terpenting dari teori ini adalah bahwa untuk mencapai keadaan kesadaran yang paling maju dan menyadari potensi yang mungkin terjadi, seseorang harus menemukan standar tertentu dari kebutuhannya, menetapkan tujuan sejatinya dalam kehidupan dan mengejar itu. ${ }^{3}$

Keharusan adanya standar tertentu yang harus ditentukan oleh seseorang dari pemenuhan kebutuhan fisiologis (makan, minum, pakaian, aksesoris, kebutuhan seks dlsb) selaras dengan ajaran dalam islam yang menuntut seseorang untuk mengendalikan perilakunya. Dalam islam, perilaku manusia dipengaruhi oleh kehendak (khatir). Kehendak inilah yang seringkali dikuasai oleh nafsu yang mendorong

${ }^{1}$ Benson, Nigel, et al. 2012. The Psychology Book: Big Ideas Simply Explained. Gabal, 2012, hal. 138.

${ }^{2}$ Benson, Nigel, et al. 2012. The Psychology Book $\cdots$, hal. 138.

${ }^{3}$ Benson, Nigel, et al. 2012. The Psychology Book $\cdots$, hal. 138. 


\section{Husnul Hidayati}

ke arah yang berlebihan (an-nafsu al-ammarah bi as-suu). Pengendalian terhadap nafsu inilah yang penting dilakukan oleh seseorang.

Sebagai upaya untuk mengendalikan dorongan nafsu yang bersifat destruktif tersebut, kalangan pesantren menempuh jalan riyadhah (latiahan), baik fisik maupun batin. Sebagai sarana untuk menngendalikan keinginan yang meluap-luap untuk memuaskan kebutuhan fisik ini, riyadhah penting untuk dilakukan. Sebagaimana menurut Abraham Maslow, bahwa meskipun kebutuhan itu bersifat instruktif terhadap perilaku, namun perilaku yang digunakan untuk memuaskan kebutuhan tersebut sifatnya dipelajari, dan dilatih. ${ }^{4}$

Setidaknya, latar belakang di atas menggambarkan sebagian dari motivasi yang melarbelakangi pelaku riyadhah puasa di Pondok Pesantren Al-Munawwir Komplek L Krapyak. Beberapa informan yang penulis wawancarai mengatakan bahwa riyadhah puasa yang mereka jalani bertahun-tahun adalah untuk melatih diri, mengolah jiwa dan membatasi keinginan yang mel uap-luap, melebihi kebutuhan yang seharusnya dipenuhi.

\section{METODE PENELITIAN}

Penelitian ini berusaha menampilkan peran riyadhah puasa sebagai model pendidikan pengendalian diri dalam memenuhi kebutuhan fisiologis. Penulis menggunakan pendektan penelitian kualitatif perspektif fenomenologi. Melalui metode ini, peneliti berusaha memahami arti riyadhah puasa dan kaitan-kaitannya terhadap pemenuhan kebutuhan fisiologis dalam situasi-situasi tertentu. Penelitian fenomenologi lahir dari tradisi paradigma konstruksionalisme yang memandang realitas sosial sebagai socially meaningfull action melalui pengamatan langsung dan terperinci terhadap perilaku sosial dalam kehidupan sehari-hari secara apa

${ }^{4}$ Syamsu Yusuf dan Juntika Nurihsan. 2012. Teori Kepribadian. Bandung: Remaja Rosdakarya Offset, hal. 156. 
adanya dan alamiah (natural). ${ }^{5}$ Dengan menggunakan metode ini, maka pengalaman yang dialami oleh pelaku riyadhah puasa berusaha penulis sampaikan secara gamblang dan apa adanya. Seperti dikutip dari Creswell, bahwa penelitian fenomenologi mendeskripsikan makna dari pengalaman hidup seseorang dan mengeksplorasi struktur kesadaran dari pengalaman kehidupan sehari-hari tersebut. ${ }^{6}$

Dalam mengumpulkan data penelitian, penulsi menggunakan metode observasi, wawancara dan kajian literatur terkait. Observasi berguna untuk memperoleh data dari tangan pertama dengan mengamati orang dan tempat pada saat dilakukan penelitian. Observasi ini penulis lakukan di lingkungan Pondok Pesantren AlMunawwir Komplek L Krapyak Yogyakarta. Sedangkan wawancara mutlak dilakukan untuk menggali makna riyadhah puasa bagi shaim tersebut, mengeksplorasi struktur kesadaran di balik laku riyadhah dan kaitannya dengan pengendalian pemenuhan kebutuhan fisiologis.

Pengolahan data peneltian ini dilakukan dengan metode naratif deskriptif. Karena data yang begitu banyak akan dilakukan pengkodingan menjadi tema-tema pembahasan tersendiri. Tematema ini yang nantinya akan dianalisis dan ditafsirkan. Analisis deskriptif dari temuan berdasarkan tema tertentu tersebut disertai dengan teori-teori yang sesuai kemudian akan ditarik sebuah kesimpulan yang dapat menjawab permasalahan penelitian. ${ }^{7}$

\section{PEMBAHASAN}

Secara bahasa, puasa berasal dari kata shaum dalam Bahasa Arab yang semakna dengan imsak yang berarti menahan atau menjaga. Sedangkan secara istilah syariat, puasa berarti menahan diri

\footnotetext{
${ }^{5}$ Jhon W. Creswell. 2000. Research Design. London: Sage Publication, hal. 51.

${ }^{6}$ Ibid. hal. 51-52.

${ }^{7}$ Jhon W. Creswell. 2000. Research Design. London: Sage Publication, hal 52.
} 


\section{Husnul Hidayati}

dari makan, minum, jima, serta segala sesuatu yang membetalkan puasa, mulai dari terbit fajar hingga tenggelamnya matahari. Puasa selain menjadi tameng seseorang dari perbuatan yang melanggar syariat, ia juga menjadi salah satu bentuk penghambaan kepada Allah untuk menggapai ridha-Nya. ${ }^{8}$ Puasa melatih seseorang untuk ikhlas, disiplin, mawas diri, amanah, jujur, dan malu karena merasa berada dalam pengawasan Allah.

Selain puasa wajib di bulan Ramadhan, Syariat Islam juga menganjurkan puasa sunnah seperti puasa hari Senin dan Kamis, puasa Dawud, puasa di tanggal 13, 14, dan 15 penanggalan hijriyah dan puasa di hari-hari tertentu yang disunnahkan. Namun, tidak hanya itu, kalangan pesantren memiliki satu tradisi riyadha puasa sebagai metode untuk melatih pengendalian nafsu. Sebab dalam islam, nafsu inilah yang senantiasa berbisik di hati seseorang yang mengarahkan perilaku orang tersebut. Bila nafsu meluap-luap, maka perilaku seseorang pun akan melampaui batas dan mungkin berakibat buruk bagi dirinya.

Kalangan pesantren mengenal banyak jenis riyadhah puasa. Tiap riyadhah puasa memiliki nama dan tata cara pelaksanan yang khusus. Puasa nganyep memiliki pantangan tidak boleh mengonsumsi makanan yang memiliki rasa (asin, manis, pahit, pedas, dan lain-lain), puasa mutih yang hanya memperbolehkan pelaku riyadhah ini mengonsumsi nasi putih, tanpa lauk danpa bumbu, atau puasa ngrowot yang hanya memperbolehkan pelaku puasa memakan makanan dari umbi-umbian seperti ketela, singkong, jagung dan sejenisnya. ${ }^{9}$

${ }^{8}$ Saputra, Johan. 2018. Ngrowot dan Tazkiyatun Nafs (studi Manfaat Ngrowot untuk Pembersihan Jiwa di Kalangan Santri Asrama Perguruan Islam (API) Pondok Pesantren Salaf Tegalrego Magelang Jawa Tengah), Skripsi Fakultas Ushuluddin Universitas Islam Negeri Sunan Kalijaga Yogyakarta, hal. 18.

${ }^{9}$ Wawancara dengan Responden 2, santri yang telah menjalani puasa nahun (dahr) selama tiga tahun. Wawancara dilaksanakan pada tanggal 9 Juni 2020. 
Selain riyadhah puasa di atas, terdapat jenis puasa yang tata caranya sama seperti puasa pada umunya dan tidak memiliki pantangan tertentu. Akan tetapi, puasa ini harus dijalani selama minimal tiga tahun tanpa putus. Bila satu hari saja batal puasa, maka orang tersebut harus mengulanginya dari hitungan awal lagi. Pelaku riyadhah puasa ini, selain menjalani puasa, juga diharuskan membaca doa atau wirid tertentu yang diijazahkan oleh seorang kiai. ${ }^{10}$

Responden 1, salah satu santri pondok pesantren AlMunawwir Komplek L Krapyak Yogyakarta menceritakan bahwa riyadhah puasa tahunan ini sudah dijalaninya selama hampir sembilan tahun hingga sekarang, terhitung sejak pertengahan tahun 2011 lalu. Sebelum menjalani puasa ini, beberapa puasa yang pernah dilakukan oleh Responden 1 adalah puasa Senin Kamis, lalu puasa dawud, kemudian puasa Dahr. Sebagaimana dipercayai oleh para santri, bahwa untuk diperbolehkan menjalani riyadhah puasa, seorang santri harus mendapatkan ijazah (restu, ajaran, rekomendasi) dari seorang kiai tertentu. ${ }^{11}$ Responden 1 mendapatkan ijazah puasa nahun itu dari seorang kyai dari Kudus yang harus dilakukan selama tiga tahun tanpa putus (kecuali di hari-hari yang diharamkan berpuasa. ${ }^{12}$

Puasa yang dijalani oleh Responden 1 itu disebut juga dengan puasa dalail, karena setiap harinya membaca kitab dalail al-khairat. Sedangkan tata carannya, setiap hari membaca bagian-bagian dari kitab dalail. Kitab dalail tersebut berisic tawassul, ada asmaul husna, dan ada asma nabi muhammad yang jumlahnya 202. Lalu membaca bagian dari kitab setiap harinya yang dibagi 7 hari. Pengamalan wirid

${ }^{10}$ Wawancara dengan Responden 1, santri yang telah menjalani puasa nahun (dahr) selama hampir sembilan tahun hingga sekarang. Wawancara dilaksanakan pada tanggal 9 Juni 2020.

${ }^{11}$ Responden 3, wawancara 9 Juni 2020.

${ }^{12}$ Dalam syariat Islam, ada hari-hari yang diharamkan menjalani puasa di hari itu. Hari-hari tersebut adalah: hari raya idul fitri dan idul adha, serta tiga hari setelah idul adha yang dikenal dengan ayyam at-tasyrik. 
tidak dibatasi pada waktu tertentu, hanya saja pengamal riyadhah tidak boleh menyepelekan. ${ }^{13}$

Responden 2 adalah santri pesantren Komplek L yang sudah selesai menjalani riyadhah puasa nahun tersebut. Ia mulai menjalani riyadhah sejak tahun 2012 sampai tahun 2015. Responden 2 mendapatkan ijazah riyadhah puasa dari seorang kyai di Klaten yang harus dijalani selama minimal tiga tahun tanpa putus dan ada doadoa tertentu. Wirid tersebut harus dibaca di hari-hari puasa dan dilaksanakan itu hanya sampai 41 hari pertama saja. Waktu membacanya dianjurkan pada malam hari, tapi jika malam itu tidak bisa, boleh dibaca siang hari. ${ }^{14}$

Berbeda dengan Responden 1 dan Responden 2 yang sudah menjalani puasa selama tiga tahun lebih, Responden 3 dapat dikatakan sebagai pemula, sebab baru sekitar dua bulan menjalani riyadhah puasa. Responden 3 mendapat ijazah puasa juga dari seorang kyai di Klaten. Puasa tahunan yang diijazahkan kepada Iqbal harus dijalani selama setahun dulu. Jika setelah satu tahun masih ingin melanjutkan puasa, Responden 3 diharuskan meminta izin lagi kepada kyai. Sama seperti puasa sebelumnya, Responden 3 juga diharuskan membaca doa atau wirid tertentub dan tidak harus malam hari. $^{15}$

Motivasi dalam menjalani riyadhah puasa juga berbeda-beda diantara ketiga santri tersebut. Sebelum puasa ini, Responden 3 menceritakan bahwa ia mengalami kejenuhan. Lalu ia ingin melatih tubuhnya dengan puasa. Awalnya Responden 3 tidak memiliki harapan yang muluk-muluk, intinya hanya ingin melatih diri, dan Iqbal menyukai puasa itu. Namun, seiring berjalannya waktu,

\footnotetext{
${ }^{13}$ Responden 3, wawancara 9 Juni 2020.

${ }^{14}$ Responden 2, wawancara 9 Juni 2020.

${ }^{15}$ Responden 3, wawancara 9 Juni 2020.
} 
Responden 3 merasa ingin melanjutkan perjuangan orang tua yang dulu juga pernah menjalani riyadhah puasa.

Berbeda dengan Responden 3, Responden 1 meyakini bahwa seorang santri atau pelajar itu harus memiliki tiga hal yang harus ditempuh. Pertama, memperbanyak pengetahuan dengan belajar, yang kedua itu berkdimah (mengabdi kepada guru dan ilmu), dan yang ketiga itu riyadhah (laku prihatin) agar ilmu ilmu yang dipelajari seorang santri itu bertuah. Menurut Imad, inti dari riyadhah puasa adalah menahan hawa nafsu, menahan apa yang anda inginkan, supaya di kemudian hari itu seorang santri yang menjalani riyadhah dapat memetik buahnya. ${ }^{16}$

Motivasi yang berbeda disampaikan oleh Responden 2. Sebagai seorang santri, ia merasa harus berkaca kepada gurunya yang semasa hidupnya sampai sekarang masih berpuasa. Responden 2 pun terinspirasi dari beliau, sebab seorang murid seyogyanya terinspirasi dengan apa yang dilakukan oleh kiai. Selain itu, motivasi Responden 3 menjalani riyadhah adalah untuk latihan mengendalikan diri. Ia berharap, suatu saat nanti jika ia ditakdirkan memiliki anak, riyadhah yang dijalaninya ini ia tujukan untuk mendoakan anaknya dan keluarganya. Bagi Responden 2, riyadhah yang dilakukan sejak masa muda tidak akan memberatkan dibanding jika dilakukan saat sudah tua. Responden 2 juga meniatkan untuk meriyadhohi ilmu yang dipelajarinya di pesantren, dan berharap mendapatkan manfaat dan berkah dari ilmu yang ia pelajari. ${ }^{17}$

\section{Ujian Selama Menjalani Riyadhah Puasa}

Sebagian besar orang menduga bahwa berpuasa selama tiga tahun penuh tanpa putus adalah sebuah hal yang sangat berat. Dalam jangka waktu selama itu, kemungkinan melemahnya himmah (tekad)

\footnotetext{
${ }^{16}$ Responden 1, wawancara 9 Juni 2020.

${ }^{17}$ Responden 3, wawancara 9 Juni 2020.
} 


\section{Husnul Hidayati}

di tengah tengah menjalani puasa sangat mungkin terjadi. Apalagi jika di musim kemarau ketika suhu udara sangat panas, atau ketika didera sakit tertentu. Hal-hal semacam itulah yang mungkin menjadi ujian kesungguhan mental serta komitmen untuk menyelesaikan puasa. Jika mampu melewati ujian itu, maka pelaku riyadhah puasa satu tingkat naik kelas.

Begitu besar dan sulitnya perang melawan hawa nafsu, kaum sufi (pengamal ajaran tasawuf) menyebut upaya itu sebagai mujahadah (perang habis-habisan) untuk menundukkan hawa nafsu. Dan untuk bisa memenangkannya, diperlukan tak kurang latihan-latihan spiritual (riyadhah an-nafs). Latihan tersebut harus terus dijalani sehingga seseorang, dalam hal ini pengamal riyadhah puasa, bisa memastikan daya tahan mereka terhadap dorongan nafsu telah menjadi tabiat kedua (second nature). Bahwa seseorang terus mawas diri dan tidak terpedaya oleh berbagai macam tipu daya nafsu yang amat lembut dan samar. ${ }^{18}$

Responden 2 menceritakan beberapa ujian yang dialaminya semasa menjalani riyadhah puasa. Secara fisik, selama menjalani puasa, tubuhnya menjadi lebih kurus, namun ia mengaku tidak pernah mengalami sakit keras selama menjalani riyadhah yang sampai membatalkan puasa. Selain ujian fisik, Responden 2 mengaku bahwa hikmah menjalani puasa baginya adalah bahwa mentalnya lebih tangguh dan lebih teruji. Ia menjadi tidak mudah tergiur dengan keinginan tertentu yang baginya tidak bermanfaat, sebab selama tiga tahun menjalani riyadhah, ia berjuang melawan nafsu. ${ }^{19}$

Secara spiritual, menurut Responden 2, riyadhah puasa adalah salah satu jalan menuju menuju wali (kekasih) Allah. Menjalani puasa selama bertahun-tahun membawa kepekaan bahwa manusia sejatinya

53-55.

${ }^{18}$ Bagir, Haidar. 2oo6. Buku Saku Tasawuf. Bandung: Mizan Media Utama, hal.

${ }^{19}$ Responden 2, wawancara 9 Juni 2020. 
adalah makhluk yang lemah. Manusia tanpa makan dan minum dari Subuh sampai Maghrib saja sudah lemas. Kesadaran semacam ini secara langsung memengaruhi terhadap kepekaan spiritual spiritual, bahwa pelaku riyadhah akan menjadi lebih sensitif, mengakui kelemahan manusia, dan mensyukuri anugerah Allah.

Tidak jauh berbeda dengan Responden 2, Responden 3 mengaku bahwa hari-hari pertama menjalani puasa membuatnya hamper tidak kuat. Responden 3 mengaku bahwa sebelumnya ia sama sekali tidak menjalani puasa sunnah sebagai ajang latihan. Ia langsung menjalani puasa tahun. Satu bulan pertama menjalani riyadhah, tubuhnya masih sering lemas dan menjadi lebih kurus. Ujian mental yang sangat berat dialami Responden 3 adalah pengendalian emosi, khususnya amarah. Namun, huingga memasuki tiga bulan menjalani puasa, ia mengaku sedikit demi sedikit mempu luapan amarah. ${ }^{20}$

Ujian yang dialami Responden 1 cenderung tidak berbeda. Menurutnya, hal itu dikarenakan ia telah menjalani puasa selama hampir sembilan tahun, sehingga bagi dia, kondisi sesulit apapun tetap tidak berdampak secara signifikan pada jiwanya. Sembilan tahun melatih diri untuk mengendalikan nafsu, membawa perasaan tenang dalam menjalani hidup. Hanya saja, menjalani puasa selama hampir sembilan tahun bukanlah hal yang umum diketahui masyarakat. Beberapa kali Responden 1 dipaksa untuk menjelaskan riyadhah puasanya tersebut kepada masyarakat. ${ }^{21}$

Akhirnya, perlu ditegaskan, sebagaimana yang dikatan oleh Responden 2, bahwa upaya untuk melawan nafsu hendaknya dilakukan sejak dini. Bukan hanya pendidikan yang dilakukan di masa dini akan lebih mudah bertahan ${ }^{22}$, melainkan juga bahwa bila

\footnotetext{
${ }^{20}$ Responden 3, wawancara 9 Juni 2020.

${ }^{21}$ Responden 1, wawancara 9 Juni 2020.

22 Ahmed, Akbar S. 1997. Living Islam: Tamasya Budaya Menyusuri Samarkand hingga Stornoway, diterjemahkan dari "From Samarkand to Stornoway: Living Islam" oleh Pangestuningsih. Bandung: Penerbit Mizan, hal. 59.
} 
tidak melatih mengendalikan nafsu, maka kehidupan di masa tua akan menjadi sia-sia. Nabi Muhammad SAW dalam sebuah hadits menegaskan, bahwa: perut (sebagai sumber nafsu terhadap makanan) Anak Adam tidak akan kenyang hingga ia dipenuhi dengan tanah (yaitu ketika telah mati dikubur). ${ }^{23}$

\section{Hikmah Menjalani Riyadhah Puasa}

Selain sebagai latihan fisik dan spiritual sebagaimana dijelaskan sebelumnya, secara sosial, puasa juga membantu seseorang dalam memahami penderitaan mereka yang kurang mampu. ${ }^{24}$ Dengan kesadaran semacam ini, maka seorang pengamal riyadhah puasa lebih mampu untuk sabar dalam setiap kondisi sulit, dan menyukuri setiap anugerah yang dimiliki, sekecil apapun itu. Sebab, tujuan utama puasa adalah untuk menyegarkan kembali kesadaran spiritualitas. ${ }^{25}$ Dengan demikian, kebahagiaan yang hakiki bagi seseorang bukanlah seberapa banyak harta yang dimiliki, tidak juga dengan selezat apapun makanan yang dikonsumsi, tetapi pada penerimaan seseorang pada diri mereka.

Berkaitan dengan kepekaan sosial seseorang dalam memahami penderitaan mereka yang kurang mampu, Responden 3 mengaku bahwa kepekaan itu muncul dari dalam dirinya semenjak menjalani puasa. Baginya, merasakan apa yang dirasakan orang yang hidupnya itu lebih berat dari, seperti orang yang mencari nafkah, namunhanya cukup untuk makan, dengan puasa kita itu mencoba merasakan apa yang dirasakan, minimal itu dengan mengurangi makan. ${ }^{26}$ Dengan kesadaran ini, ia mengaku lebih dapat mensyukuri nikmat dari Allah, seperti yang mereka nikmati.

55.

${ }^{23}$ Bagir, Haidar. 2oo6. Buku Saku Tasawuf. Bandung: Mizan Media Utama, hal.

${ }^{24}$ Ahmed, Akbar S. 1997. Living Islam: Tamasya Budaya $\cdots$, hal. 59.

${ }^{25}$ Ahmed, Akbar S. 1997. Living Islam: Tamasya Budaya $\cdots$, hal. 61.

${ }^{26}$ Responden 3, wawancara 9 Juni 2020. 
Hikamh di balik riyadhah puasa juga dialami oleh Responden 1. Selama hampir sembilan tahun berpuasa, ia memaknai kebahagiaan yang hakiki itu ketika ia tidak banyak pikiran. Ia lebih tenang dalam menjalani hidup. Tidak mudah tertekan oleh tekanan sekitar. Kesadaran bahwa setiap gerak gerik seseorang dalam hidup tidak akan lepas dari pengawasan Allah Swt, menjadikannya lebih mampu merasa dekat kepada Allah. Perasaan religius yang lebih besar ini meringankan beban pikiran Imad, sebab dengan meningkatnya kesadaran spiritual, seseorang menjadi lebih ringan pikiran. ${ }^{27}$ Sebab, setelah menjalani latihan latihan ini melalui puasa, Responden 1 sudah terbiasa menghadapi tekanan lapar.

Kondisi terbiasa menahan lapar, haus, emosi dan hal-hal buruk lainnya dalam kurun waktu tiga tahun membawa Responden 2 pada kesadaran spiritual tentang sabar dan syukur. Dua hal inilah kiranya yang hikmah yang dialaminya, sabar ketika sedang mengalami kesulitan, dan syukur ketika sudah bisa makan. Apapun yang didapatkan oleh Responden 1, yang penting baginya adalah mampu bersyukur.

"Ada harta lebih kita bisa bersyukur. Itu yang yang yang kita latih. Jangan sampai ada kejadian atau istilahnya apa ya, kehidupan ini yang tidak ada korelasinya antara sabar dan syukur tersebut. Yang dilatih ketika riyadhah puasa itu bagaimana kita sabar ketika lapar. Ketika berbuka puasa kita bersyukur, apa pun itu, sedikit banyaknya, apapun wujudnya, kita sabar dan kita syukur. Kalau setiap hal yang bisa kita syukuri, kita akan mememukan kebahagiaan dalam hidup."

Al-Ghazali dalam Minhaj Ath-Thalibin menjelaskan bahwa macam-macam sabar ada tiga; sabar dalam menjalani cobaan, sabar dalam menjalani ketaatan, dan sabar dalam menahan diri dari

${ }^{27}$ Ahmed, Akbar S. 1997. Living Islam: Tamasya Budaya ' , hal. 61. 
maksiat, ${ }^{28}$ dan ketiga macam sabar tersebut dilatih dalam riyadhah puasa secara bersamaan.

\section{Kebutuhan Fisiologis}

Dalam memenuhi kebutuhan dasarnya, manusia dipenuhi oleh kebutuhan-kebutuhan intuitif yang muncul dari dalam dirinya. Abraham maslow menyebut bahwa pilihan tindakan manusia dipengaruhi oleh adanya kebutuhan dasar manusia (basic human needs) yang mau tidak mau harus terpenuhi (basic human needs have a striving or motivational character). ${ }^{29}$ Manusia, menurut Maslow, diorganisasikan ke dalam sebuah hierarki kebutuhan dasar yang sistematis, mendahului kebutuhan dasar yang lainnya. Oleh karena adanya tuntutan untuk memenuhi kebutuhan dasar tersebut, manusia terdorong (termotivasi) untuk mencari upaya-upaya (efforts) pemenuhan kebutuhan. Bila kebutuhan dasarnya terpenuhi, manusia akan merasa puas (satisfied), begitu pula sebaliknya. ${ }^{30}$

Secara hierarkis, basic human needs menurut masliw terdiri dari lima kebutuhan dasar, dimulai dari yang paling dasar adalah kebutuhan fisiologis (physiological needs), kebutuhan rasa aman (safety and security needs, kebutuhan pengakuan dan kasih sayang (belongingness and love needsi), kebutuhan penghargaan (esteem needs), kebutuhan kognitif (cognitive needs), kebutuhan estetika (aesthetic needs), dan kebutuhan aktualisasi diri (self-actualization). Kebutuhan yang paling rendah dalam hierarki merupakan kebutuhan yang potensial, kuat, dan prioritas. Bila kebutuhan yang paling rendah ini diabaikan, maka seseorang akan mengalami defisiensi (ketidaknyamanan) dalam hidup. ${ }^{31}$

${ }^{28}$ Al-Imam Abu Hamid Muhammad bin Muhammad al-Ghazali. Tt. Minhaj Ath-Thalibin. (Surabaya: Dar Al- "Ilm) hal. 54-55.

${ }^{29}$ Feist, J., \& Feist, G. J. (2008). Theories of personality. McGraw-Hill, hal. 280.

${ }^{30}$ Feist, J., \& Feist, G. J. 2008. Theories of personality $\cdots$, hal. 280.

${ }^{31}$ Yusuf, Syamsu dan Juntika Nurihsan. 2012. Teori Kepribadian *, hal. 156. 
Sebagai kebutuhan manusia yang paling dasar, kebutuhan fisiologis penting dipenuhi sebagai langkah mempertahankan hidupnya secara fisik, yaitu kebutuhan akan makanan, minuman, pakaian, seks, istirahat, dan oksigen. ${ }^{32}$ Makanan adalah kebutuhan dasar manusia yang paling utama dan pemenuhannya adalah bagian dari hak asasi manusia. Dalam konteks Indonesia, pemenuhan akan kebutuhan makanan ini dijamin dalam Undang-undang Dasar Republik Indonesia tahun $1945 .{ }^{33}$

Kebutuhan akan pakaian adalah kebutuhan dasar manusia selain makanan yang berfungsi untuk melindungi tubuh dari panas dan dingin dan untuk menjaga nilai kesopanan sebagai makhluk berbudaya. Selain itu, kebutuhan fisiologis lain yang dibutuhkan oleh manusia adalah kebutuhan kesehatan yang mencakup kesehatan fisik, mental dan sosial. Maslow mengemukakan bahwa manusia adalah binatang yang berhasrat dan jarang mencapai taraf kepuasan yang sempurna. Kecuali hanya dalam waktu yang sesaat. Apabila satu hasrat telah terpuaskan, maka hasrat lain muncul sebagai penggantinya.

\section{Pemenuhan Kebutuhan Fisiologis}

Menurut Maslow, orang yang merasa lapar akan termotivasi untuk makan. Mereka tidak menginginkan hal lain selain makanan. Selama kebutuhan ini tidak terpenuhi, motivasi utama mereka adalah untuk mendapatkan sesuatu untuk dimakan. Dalam masyarakat yang makmur, mereka biasanya memiliki cukup makanan, sehingga ketika mereka mengatakan mereka lapar, yang mereka kehendaki sebenarnya adalah tentang selera, bukan kelaparan. Orang yang

\footnotetext{
${ }^{32}$ Yusuf, Syamsu dan Juntika Nurihsan. 2012. Teori Kepribadian '., hal. 159-160.

${ }^{33}$ Rizqiyah, A Z, dkk. 2019. Efforts of Young Parents In Meeting Childrens Physiological Needs. IOP Publishing, hal. 3.
} 


\section{Husnul Hidayati}

benar-benar lapar tidak akan terlalu berlebihan khususnya tentang rasa makanan, bau, suhu, atau tekstur makanan. ${ }^{34}$

Dari penjelasan tersebut, secara tidak langsung Maslow ingin mengatakan bahwa sebenarnya pemenuhan kebtuhan fisiologis itu cukup sederhana. Dalam contoh kebutuhan akan makanan, seseorang sebenarnya hanya membutuhkan makanan penghilang lapar, dan tidak harus selalu menuruti selera. Hal ini penting untuk dipahami, sebab, bila merujuk pada konsep hierarki kebutuhan dasar manusia ini, semakin sederhana standar pemenuhan kebutuhan fisiologis, maka seseorang akan mudah untuk melewati kebutuhan itu, dan mengupayakan kebutuhan di atasnya, secara sederhana, dan seterusnya hingga seseorang benar-benar mencapai tahap aktualisasi diri sebagai pribadi yang matang.

Dalam memaknai standar kebutuhan yang harus dipenuhi oleh seseorang, Responden 2 memberikan pemaknaannya sendiri. Ia mengatakan bahwa jika memang kebutuhan untuk menghilangkan lapar bisa terpenuhi dengan satu piring nasi, lauk dan tempe, seseorang seharusnya tidak memaksakan diri untuk memakan dua piring nasi, atau harus selalu makanan yang lezat.

“Kembali ke kebutuhan apa yang harus kita penuhi. Kalau misalkan kita cukup dengan makan satu piring ya kenapa harus dua piring? Dalam arti, serakah itu pasti akan mati dengan sendirinya, karena terbiasa dengan hidup sederhana, apa adanya, sederhana hidup enggak perlu harus punya ini dan itu yang tidak ada manfaatnya dan pikiran-pikiran kotor. Pengendalian diri iru lebih terasah. Jadi lebih bisa mengendalikan nafsu gitu loh. Jadi enggak neko-neko. Kalau misalkan sekali-kali kita makan di McD kan gapapa. Kan namanya

${ }^{34}$ Feist, J., \& Feist, G. J. (2008). Theories of personality. McGraw-Hill, hal. 283. 
hidup itu tidak harus montoton, bisa ada variasinya, tapi jangan sampai keluar dari koridor tidak, harus dikendalikan.” 35

Dalam sebuah hadits, Nabi Muhammad Saw mengatakan: umatku tidak makan kecuali dalam keadaan lapar, dan berhenti sebelum kenyang". Dari hadits ini, Nabi mengajarkan bahwa orang yang berpuasa, bukankah ia amat sangat ingin menyegerakan berbuka untuk menghilangkan laparnya? Tapi itu pun oleh Nabi diajarkan agar kita berhenti sebelum kenyang. Artinya, Nabi memang memberikan pendidikan agar seseorang belajar mengendalikan nafsu yang melebihi kebutuhan sebenarnya. Responden 3 sangat memahami pentingnya pengendalian nafsu ini. Ia menganalogikan nafsu sebagai kuda, sedangkan manusia sebagai kusirnya. "Kalau masalah nafsu yang secara umum ya masih ada. Nafsu itu ibarat kuda, kita harus mengontrol kuda tersebut. Dalam hidup kita nerimo lah, nrimo ing pandum. Jadi lebih ridho" ${ }^{36}$

Kiranya, menentukan standar yang sederhana dalam memenuhi kebutuhan fisiologis sebagaimana diajarkan oleh Nabi Muhammad itu sangatlah penting. Sebab, bila seseorang tidak melatih diri agar terbiasa dengan kesederhanaan, maka orang tersebut cenderung tidak akan puas. Ketidakpuasan yang terus-menerus ini, menurut Erich Fromm dapat mengakibatkan gangguan mental. Dengan demikian, orang-orang sangat terdorong untuk memenuhinya dengan berbagai cara, baik secara positif maupun negatif, ${ }^{37}$ dan menuruti nafsu inilah yang dilarang dalam islam, sehingga harus dilatih melalui riyadhah puasa.

${ }^{35}$ Responden 2, wawancara 9 Juni 2020.

${ }^{36}$ Responden 3, wawancara 9 Juni 2020.

${ }^{37}$ Feist, J., \& Feist, G. J. (2008). Theories of personality. McGraw-Hill, hal. 195. 


\section{Aspek Pendidikan dari Riyadhah Puasa dalam Pemenuhan Kebutuhan Fisiologis}

Al-Ghazali menegemukakan pandangannya tentang model motivasi konsumsi. Dalam pemikirannya, titik tekan motivasi tersebut berorientasi pada prinsip maslahah yang mengandung utility dan etika. Prinsip mashlahah ini menurut Al-Ghazali menjadikan konsumsi seseorang terhadap makana atau barang dapat membawa barakah. ${ }^{38}$ Al-Ghazali juga menkankan bahwa tujuan utama dalam proses pemenuhan kebutuhan manusia memiliki tujuan untuk mempertahankan lima tujuan hidup manusia yang meliputi: ad-din (agama), an-nafs (jiwa), al-mal (harta), al-aql (akal), dan an-nasl (reproduksi). Kelima prinsip inilah yang disebut oleh Al-Ghazali sebagai maslahah. ${ }^{39}$

Namun, mengingat bahwa seluruh kebutuhan manusia itu tidak sama kadar pentingnya, Al-Ghazali dengan cermat membagi kebutuhan manusia tersebut menjadi tiga: darurat (kebutuhan primer), hajat (kebutuhan sekunder), dan tahsiniyat (kebutuhan pelengkap). Kebutuhan darurat merupakan tujuan yang harus ada dan mendasar bagi penciptaan kesejahteraan di dunia dan akhirat, yaitu mencakup terpeliharanya lima elemen dasar kehidupan, yakni jiwa, keyakinan atau agama, akal atau intelektualitas, keluarga atau reproduksi, serta harta benda. Jika kebutuhan darurat ini diabaikan, maka tidak ada kedamaian, bahkan yang timbul adalah kerusakan (fasad) di dunia dan akhirat. ${ }^{40}$

Dalam menjelaskan batasan kebutuhan darurat ini, Al-Ghazali menggunakan istilah sadr-ramq (subsisten). Sadr-ramq adalah

${ }^{38}$ Mirshad, Zaki. 2014. Motivasi Konsumsi Islam Versus Sekuler: Studi Komparatif Pemikiran Al-Ghazali dan Abraham Maslow, Thesis Program Studi Ekonomi Islam, Konsentrasi Ekonomi Islam, Pascasarjana, UIN Sunan Ampel Surabaya, hal. 67.

${ }^{39}$ Mirshad, Zaki. 2014. Motivasi Konsumsi Islam ․, hal. 67.

${ }^{40}$ Mirshad, Zaki. 2014. Motivasi Konsumsi Islam ’, hal. 68. 
tingkatan pemenuhan kebutuhan paling rendah dan bila manusia berada dalam kondisi itu, ia hanya mampu bertahan hidup dengan penuh kelemahan dan kesusahan. Al-Ghazali menolak gaya hidup seperti ini, karena seseorang tidak akan mampu melaksanakan kewajiban agama dengan baik. Al-Ghazali juga menjelaskan bahwa prinsip maslahah ini bersifat hakiki. Artinya, menurut Al-Ghazali, mengupayakan manfaat dan menolak kemudharatan itu adalah tujuan dari syariat islam. ${ }^{41}$

Kebutuhan manusia selanjutnya adalah hajat. Kebutuhan ini bertujuan untuk memudahkan kehidupan dan menghilangkan kesempitan. Hukum syariat dalam kategori ini tidak dimaksudkan untuk memelihara lima hal pokok yang telah dijelaskan sebelumnya, tetapi untuk menghilangkan kesempitan dan berhati-hati terhadap pemunuhan lima hal pokok di atas. Seandainya kebutuhan hajat ini tidak terpenuhi maka tidak akan merusak kehidupan manusia, namun keberadaan kebutuhan hajat ini dibutuhkan untuk memberikan kemudahan dalam kehidupan.

Sedangkan kebutuhan tingkat tahsiniyat (kebutuhan penyempurna) menghendaki kehidupan yang indah dan nyaman. Terdapat beberapa provisi syariat yang dimaksudkan untuk mencapai pemanfaatan yang lebih baik, seperti diperbolehkannya memakai baju yang nyaman dan indah. Karena sifatnya hanya pelengkap, maka tanpa kebutuhan ini pun kehidupan seseorang tidak akan sampai pada kerusakan $(f a s a d) .{ }^{42}$ Sebagaimana diakui oleh Responden 3, meskipun mejalani riyadhah puasa, ia tidak hanya memenuhi kebutuhan hajatnya saja, tapi sesekali ia juga mengonsumsi makanan yang menurutnya lezat.

${ }^{41}$ Mirshad, Zaki. 2014. Motivasi Konsumsi Islam '., hal. 70.

${ }^{42}$ Mirshad, Zaki. 2014. Motivasi Konsumsi Islam ․, hal. 75. 


\section{Husnul Hidayati}

"Kalo makan tuh, saya kadang pengen yang enak. Tapi ya sesekali. Lebih bisa mengontrol nafsu nafsu konsumtif."

Responden 1 memaknai pemenuhan kebutuhannya dengan pengertian yang sederhana. Menurutnya, dalam hal berpakaian, seseorang tidak harus mengenakan pakaian yang mewah. Tapi cukup pakaian yang pantas, nyaman dan awet.

"Kita jadi menerima. Kita jadi cukup dalam berpakaian. Contoh dalam pakaian, kita tidak perlu mewaah banget, yang penting awet. Kita itu nggak untuk pamer. Kelau makanan, ya kita makan seadanya. Kadang memnag gak ada, pernah sih. Tapi gak sampai yang kelaparan banget. Tidak harus selalu yang enakenak. Sesekali enak itu nggak apa-apa. Tapi tidak terus-terusan. ",

Manfaat menjalani riyadhah puasa yang paling kentara dialami oleh Responden 2. Ia mengaku, sebelum menjalani riyadhah, ia sering sekali makan di McD atau KFC yang bagi kalangan santri kedua tempat tersebut sudah dianggap "mewah" . Namun itu berbanding terbalik setelah Responden 2 menjalani riyadhah puasa selama tiga tahun.

"Sebelum riyadhoh puasa ini, saya itu sering makan kalau nggak di McD ya KFC. Dan itu berbanding terbalik setelah menjalani riyadoh. Ya kalau kebutuhan pokok sandang, paipan dan pangan itu harus. Namanya manusia tidak bisa lepas dari hal pokok yang penting itu. Kalau kita cukup dengan makan satu piring dengan lauk dan 1 butir tempe itu cukup, terus kita memaksakan diri makan banyak tempe itu namanya kan sudah melampaui kebutuhan kita sekarang. Kalau kita cukup makan satu piring, kenapa makan dua piring? Buat apa? Yang dilatih ketika puasa itu, kita lebih tahu sih, mana yang menjadi kebutuhan kita, mana yang jadi nafsu kita.

Responden 2 mengalami perubahan cara pandangnya terhadap pemenuhan kebutuhan. Ia lebih tahu mana yang benar-benar menjadi 
kebutuhan, dan mana yang menuruti nafsu. Dalam hal pakaian pun, Rahmat mengaku menjadi lebih selektif. Kalau misalkan sudah memiliki tujuh sarung, sepuluh baju misalnya, kemudian di toko melihat ada yang menarik dan muncul keinginan untuk membeli, Rahmat menjadi lebih berpikir, "Bener nggak sih aku butuh baju itu pakai itu? Manfaat puasa pasti akan lebih baik mengenal diri sendiri” .43

Bagi Responden 2, dengan mengenali diri sendiri dan sensitif terhadap kebutuhan apa yang sebenarnya harus terpenuhi, puasa juga pada akhirnya membiasakannya dalam mengambil berbagai keputusan-keputusan krusial dalam hidup. Responden 2 juga lebih mumpuni dalam menysuun skala prioritas kebutuhan, tahu kebutuhan apa saja yang harus dipenuhi dan mana yang harus ditinggalkan. Dan pengetahuan inilah yang disebut dengan mengendalikan nafsu.

\section{PENUTUP}

Pemenuhan kebutuhan dasar fisiologis mutlak harus dipenuhi untuk menjaga kelangsungan hidup dan mencapai kebahagiaan. Namun, untuk mampu memenuhi kebutuhan tersebut, seseorang harus menentukan standar minimal tertentu. Bila merujuk pada hierarki kebutuhan dasar manusia menurut Abraham Maslow, kebutuhan fisiologis berada paling dasar dari empat kebutuhan lain. Artinya, untuk mampu memenuhi kebutuhan di atasnya hingga melakukan aktualisasi diri, seseorang harus mampu memenuhi kebutuhan di bawahnya. Jika tidak, seseorang selama hidup hanya disibukkan untuk mengejar pemenuhan kebutuhan dasar tersebut tanpa henti. Artinya pula, agar terpenuhi, standar pemenuhan pun harus ditentukan.

\footnotetext{
${ }^{43}$ Responden 2, wawancara 9 Juni 2020.
} 
Riyadhah puasa yang diamalkan oleh tiga santri pondok Pesantren Al-Munawwir komplek L selama bertahun-tahun, membantu mereka menentukan standar minimal dalam memenuhi kebutuhan dasar fisiologis tersebut. Riyadhah yang semata-mata ditujukan lillahi taala ternyata membawa hikmah yang mendalam bagi para pengamalnya dalam memaknai hidup. Selain kebahagiaan hakiki yang didapat, menurut pendapat Al-Ghazali, pemenuhan kebutuhan fisiologis oleh pengamal riyadhah puasa tersebut juga membawa keberkahan di dunia, dan akhirat.

\section{DAFTAR RUJUKAN}

Ahmed, Akbar S. 1997. Living Islam: Tamasya Budaya Menyusuri Samarkand hingga Stornoway, diterjemahkan dari "From Samarkand to Stornoway: Living Islam" oleh Pangestuningsih. Bandung: Penerbit Mizan.

Al-Imam Abu Hamid Muhammad bin Muhammad al-Ghazali. Tt. Minhaj Ath-Thalibin. Surabaya: Dar Al- "Ilm.

Bagir, Haidar. 2oo6. Buku Saku Tasawuf. Bandung: Mizan Media Utama.

Benson, Nigel, et al. 2012. The Psychology Book: Big Ideas Simply Explained. Gabal, 2012.

Creswell, Jhon W. 2000. Research Design. London: Sage Publication.

Feist, J., \& Feist, G. J. 2008. Theories of Personality. McGraw-Hill.

Mirshad, Zaki. 2014. Motivasi Konsumsi Islam Versus Sekuler: Studi Komparatif Pemikiran Al-Ghazali dan Abraham Maslow, Thesis Program Studi Ekonomi Islam, Konsentrasi Ekonomi Islam, Pascasarjana, UIN Sunan Ampel Surabaya.

Rizqiyah, A Z, dkk. 2019. Efforts of Young Parents In Meeting Childrens Physiological Needs. IOP Publishing.

Saputra, Johan. 2018. Ngrowot dan Tzkiyatun Nafs (Studi Manfaat Ngrowot untuk Pembersihan Jiwa di Kalangan Santri Asrama 
Perguruan Islam (API) Pondok Pesantren Salaf Tegalrego Magelang Jawa Tengah), Skripsi Fakultas Ushuluddin Universitas Islam Negeri Sunan Kalijaga Yogyakarta.

Yusuf, Syamsu dan Juntika Nurihsan. 2012. Teori Kepribadian. Bandung: Remaja Rosdakarya Offset. 
Husnul Hidayati

134 | Millah Vol. 20, No. 1 Agustus 2020 